\title{
PERANAN GURU BIMBINGAN DAN KONSELING DALAM UPAYA MENGURANGI TINGKAT KECEMASAN SISWA MENGHADAPI UJIAN NASIONAL
}

\author{
Nina Mardiana \\ Program Studi Bimbingan dan Konseling \\ Fakultas Ilmu Pendidikan dan Pengetahuan Sosial \\ Universitas Indraprasta PGRI
}

\begin{abstract}
The purpose of this study was to analyze how to lead counceling and guiding teacher in order to minimize anxiousty student level in national final test at the Tangerang Nusantara I Senior High School, The Goals of this research was to find out counseling and guiding program in order how to anxious overcome in implementing national final test. Researches used qualitative research methodsdescriptive, while collecting data using primary data through field research, and the instrument or means of collecting data in the form of questionnaires through Probability Sampling techniques to select the Simple Random Sampling, meaning simple random sampling to 124 grade XII students. Based on the analysis, it can be argued that conclusions lead counceling and guiding teacher to minimize student level in implementing national final test is adequate category
\end{abstract}

Keywords : Guiding and Counseling, Anxious, National Final Test

\begin{abstract}
ABSTRAK
Penelitian ini bertujuan untuk mengetahui Peranan Guru Bimbingan dan Konseling dalam upaya mengurangi tingkat Kecemasan Siswa Menghadapi Ujian Akhir Nasional dilingkungan SMA Nusantara I Kota Tangerang. Tujuan dari penelitian adalah untuk mengetahui program bimbingan dan konseling dalam upaya mengatasi kecemasan pada saat melaksanakan Ujian Akhir Nasional. Peneliti menggunakan metode penelitian kualitatif dengan pendekatan deskriptif. Sumber data adalah guru Bimbingan dan Konseling, dan siswa siswi sebagai data primer, SMA Nusantara I Kota Tangerang melalui teknik pengambilan sampel Probability Sampling dengan memilih Simple Random Sampling, yaitu pengambilan sampel sederhana secara acak kepada siswa kelas XII IPA dan IPS yang berjumlah 124 siswa. Instrument atau alat pengumpul datanya berupa angket, pedoman wawancara, dan pedoman observasi. Teknik analisis data angket dilakukan dengan cara menstabulasikan data jawaban siswa, kemudian diinterpretasikan yang akan disimpulkan. Hasil penelitian disimpulkan bahwa Peranan Guru Bimbingan dan Konseling dalam upaya mengurangi tingkat kecemasan siswa pada saat melaksanakan Ujian Akhir Nasional di SMA Nusantara I Tangerang -Banten termasuk dalam kategori cukup.
\end{abstract}

Kata Kunci: Bimbingan dan Konseling, Cemas, Ujian Akhir Nasional 


\section{PENDAHULUAN}

Kecemasan adalah manifestasi dari berbagai proses emosi yang bercampur baur, yang terjadi ketika orang sedang mengalami tekanan perasaan (frustasi) dan pertentangan batin (konflik). Kecemasan ini mempunyai segi yang disadari, seperti rasa takut, terkejut, tidak percaya, rasa berdosa, bersalah, terancam, dan sebagainya. Rasa cemas itu terdapat dalam semua gangguan jiwa. Selain itu, salah satu sebab kecemasan di antaranya pada saat menjelang Ujian Akhir Nasional siswa sibuk mempersiapkan diri terkadang mengalami rasa cemas yang berlebihan. Kecemasan tersebut timbul karena mereka merasa takut dan terlalu memikirkan hasil ujiannya kelak, padahal mereka belum berusaha sehingga kecemasan ini harus diatasi agar tidak berpengaruh buruk terhadap perkembangan mental. Kecemasan ini dapat memecah belah pemikiran seseorang, membagi dua pikiran seseorang menjadi niat yang baik dan buruk terkadang seseorang merasa pesimis karena kecemasan, sekalipun seseorang yang sesungguhnya mempunyai otak yang cerdas dan kenyataan ini telah dibuktikan dengan nilai-nilai ujian sekolah yang dicapainya dalam pelajaran, tetapi saat ia mengikuti Ujian Akhir Nasional ternyata ia mengalami kegagalan hal ini dapat mengakibatkan goncangan mental yang dialaminya, inilah bukti kecemasan sehingga kecemasan ini harus diatasi agar tidak berpengaruh buruk. Catatan Kompas (dalam hara-kiri 2010) mendekati Ujian Nasional (UN) ribuan siswa disejumlah daerah di Indonesia, dihinggapi rasa cemas dan takut tidak lulus UN, sejumlah siswa menangis, bahkan pingsan karena mereka khawatir tidak lulus UN. Siswa sebenarnya tidak perlu menangis, jika mereka rajin belajar dan berusaha maksimal, apalagi pemerintah sudah menyiapkan ujian susulan untuk seluruh tingkatan mulai dari SD, SMP, SMA, SMK, MA dan sekolah setingkatnya.

Guna meningkatkan kredibilitas Ujian Nasional, Kemendiknas mengadakan survei sebelum pelaksanaan ujian kepada peserta. Survey ini menganalisis sejauhmana keberadaan UN dapat mendorong semangat belajar siswa. Survey dilakukan dengan metode sampling di 33 Propinsi, dengan membagikan questioner kepada siswa, ada 4 (empat) pertanyaan dalam questioner yaitu pertanyaan

1. Bagaimana perasaan siswa menghadapi Ujian Nasional (UN)? Siswa menjawab biasa saja 40,5\%, siswa menjawab tidak biasa $40,2 \%$ dan siswa menjawab sangat tidak biasa $19,3 \%$

2. Bagaimana keyakinan siswa terhadap kelulusan? Siswa menjawab tidak khawatir dan yakin $25,6 \%$, siswa menjawab khawatir $7,2 \%$, dan siswa menjawab sangat khawatir $37,2 \%$

3. Bagaimana Tingkat Kecemasan siswa dalam menghadapi UN? Siswa menjawab biasa saja $21,6 \%$, siswa menjawab cemas $56 \%$ dan siswa menjawab sangat cemas $22,4 \%$.

4. Pendapat siswa tentang diselenggarakan nya UN? Siswa menjawab sangat mendorong belajar 43,7\%, siswa mendorong belajar $35,4 \%$ dan siswa menjawab tidak mendorong belajar 20,9\%

Pertanyaan pertama dan kedua memiliki korelasi yang kuat, yaitu bagaimana tingkat kecemasan siswa dalam menghadapi Ujian Nasional, dan apa pendapat mereka tentang Ujian Nasional? Dari jawaban mereka diperoleh persentase bahwa $56 \%$ siswa merasa cemas dalam menghadapi Ujian Nasional . Dari grafik yang dipaparkan Mendiknas Prof. Mohammad Nuh Dea di gedung Kemdikbud (Jum'at 20-042012), bahwa $79,1 \%$ siswa merasa terdorong belajarnya karena Ujian Nasional, dan 20,9\% siswa merasa bahwa Ujian Nasional tidak memiliki efek pendorong bagi mereka untuk belajar. Gantina Komalasari , M.Psi dan Herdi, M.Pd (Jurusan Bimbingan dan Konseling Universitas Negeri Jakarta) mengatakan bahwa dengan menggunakan metode deskriptif dengan teknik survey, tingkat kecemasan siswa kls XII SMA Negeri di Provinsi DKI Jakarta dalam menghadapi Ujian Nasional tahun ajaran 2010/2011 sebagai sampel dalam penelitian ini berjumlah 404 orang siswa yang dijaring dengan menggunakan teknik purposive sampling yaitu siswa kls XII yang mengikuti Ujian Nasional. Hasil penelitian menunjukkan bahwa siswa kls XII SMA Negeri di Provinsi DKI Jakarta tahun ajaran 2010/2011 mengalami kecemasan pada tingkat kecemasan tinggi 4,2\% (17 orang), kecemasan sedang 60,4\% (244 orang) kesemasan rendah 35,4\% (143 orang). Sebagai pembanding seperti diketahui disalah satu Sekolah Menengah Atas di Jakarta jumlah siswa yang mengalami kecemasan dalam Ujian Akhir Nasional (UAN) dengan tingkatan, klasifikasi jumlah siswa yaitu tingkatan 4-7 klasifikasi rendah dengan jumlah 71 siswa, kemudian tingkatan 7,1-13 klasifikasi sedang dari jumlah 125 siswa dan tingkatan13,1 
-16 dengan klasifikasi tinggi dari 4 siswa dari tabel di atas, dapat digambarkan bahwa 125 siswa memiliki tingkat kecemasan sedang , 71 siswa memiliki tingkat kecemasan yang rendah , dan 4 siswa memiliki tingkat kecemasan yang tinggi. Nila rata-rata dari total skor kecemasan adalah 8,1 rata-rata 8,1 masuk dalam tingkatan yang sedang. Maka, dapat disimpulkan bahwa pada kelas XII SMA X memiliki tingkat kecemasan yang sedang dalam menghadapi Ujian Nasional.

Bagi siswa, ujian nasional menjadi momok yang terus membayangi disebabkan oleh setiap tahunnya nilai standar kelulusan oleh pemerintah selalu dinaikkan, Hal itu membuat siswa yang mau mengikuti ujian nasional merasa cemas dan takut tidak lulus dalam ujian nasional. Selain itu, ujian nasional sebagai penentu kelulusan pendidikan formal, juga menjadikan beban tersendiri yang membuat pikiran mereka menjadi resah dan gelisah. Keresahan dan kegelisahan siswa tersebut menjadikan kecemasan tersendiri dalam menghadapi ujian nasional. Kecemasan bisa menjadi beban dan membuat para peserta ujian nasional menjadi takut, tertekan, dan depresi menghadapi ujian nasional dan sangat tidak menutup kemungkinan berdampak pada gangguan psikologis jika nantinya gagal atau tidak lulus ujian nasional. Namun demikian ujian nasional memiliki dampak positif dan dampak negatif bagi psikologis siswa.

Dampak positif dari ujian nasional bagi siswa selain telah disebutkan di atas, yaitu siswa akan termotivasi untuk semangat belajar, siswa akan mulai bersaing dengan siswa yang lain untuk mendapatkan nilai ujian nasional yang lebih tinggi, dan sebagai alat penngendali mutu pendidikan secara nasional.

Dampak negatif dari ujian nasional bagi siswa selain telah disebutkan di atas, di antaranya adalah stress terhadap siswa dan beban moral bagi guru, over reaktif, cenderung melakukan kecurangan, siswa harus menyiapkan belajar extra untuk mengikuti les atau bimbingan belajar, bahkan siswa kehilangan waktu untuk bermain. Siswa akan merasakan ketakutan dan kecemasan pada dirinya. Bagi Siswa yang kurang siap mental akan terganggu kesehatannya, baik kesehatan fisik maupun psikologis . Dampak negatif dari ujian nasional harus segera diatasi karena dapat menganggu siswa dalam mencapai prestasi belajar dan kesehatan fisik atau mental siswa, maka perlu adanya upaya-upaya tertentu untuk mencegah dan menguranagi atau meminimalisasi kecemasan siswa, di sinilah peran guru bimbingan dan konseling, peran institusi terkait, pemerintah dan masayarakat serta para orangtua siswa untuk membantu meredam kecemasan siswa dalam menghadapi ujian nasional. Berdasarkan latar belakang di atas dapat diidentifikasi berbagai masalah di antaranya adalah sebagai berikut :

1. Faktor apa saja yang menyebabkan kecemasan siswa kelas XII di SMA Nusantara I Kola Tangerang dalam mengbadapi Ujian Akhir Nasional (UAN)

2. Mengapa tingkat kecemasan siswa sangat berpengaruh terhadap hasil Ujian Akhir Nasional.

3. Sejauhmana peranan guru Bimbingan dan Konseling dalam meminimalisir tingkat kecemasan siswa dalam menghadapi pelaksanaan ujian akhir nasional

4. Upaya-upaya apa saja yang harus dilakukan untuk meminimalisir tingkat kecemasan siswa dalam menghadapi Ujian Akhir Nasional

Berdasarkan latar belakang dan identifikasi masalah yang telah dikemukakan diatas, penulis batasi ruang lingkup pembahasan dalam penelitian ini adalah "Peranan Guru Bimbingan dan Konseling dalam mengurangi tingkat kecemasan siswa kls XII SMA Nusantara I Kota Tangerang dalam menghadapi Ujian Nasional”.

Sesuai dengan pembatasan dan perumusan masalah di atas, penelitian ini bertujuan untuk mengetahui

1. Peranan guru bimbingan dan konseling dalam meminimalisir tingkat kecemasan siswa kls XII SMA Nusantara I kota Tangerang dalam menghadapi Ujian Akhir Nasional:

2. Faktor-faktor yang melatarbelakangi terjadinya kecemasan siswa kls XII SMA Nusantara 1 Kota Tangerang dalarn menghadapi UAN

3. Bentuk pelaksanaan bimbingan dan konseling terbadap siswa kls XII SMA Nusantara I kota Tangerang yang mengalami kecemasan dalarn menghadapi Ujian Akhir Nasional

\section{Pengertian Bimbingan}

Bimbingan adalah suatu proses bantuan atau pertolongan yang ditujukan kepada seseorang yang sedang mengalami masalah 
yang tidak dapat diatasi sendiri dan untuk mengembangkan potensi dirinya. Bimbingan dilaksanakan oleh seseorang yang mempunyai keahlian dalam bidangnya. Dalam proses bimbingan, seorang guru bimbingan dan konseling mengarahkan seseorang yang dibimbing agar dapat pemecahan masalah yang dihadapinya. (Prayitno dan Erman Amti, 2004:94). (Hamdani, 2012:81) Bimbingan adalah Proses pemberian bantuan kepada siswa, dengan memperhatikan siswa itu sebagai individu dan mahluk sosial serta memperhatikan adanya individu, agar ia dapat membuat tahap maju seoptimal mungkin dalam proses perkembangannya dan ia agar dapat menolong dirinya menganalisis dan memecahkan masah-masalahnya. Semua ini bertujuan memajukan kebahagiaan hidup, terutama ditekankan pada kesejahteraan mental.

Menurut Djurnhur dan Moh. Surya (1998:18) yang dikutip kembali oleh Hamdani berpendapat bahwa bimbingan adalah Suatu proses pemberian bantuan yang terus menerus dan sistematis kepada individu dalam memecahkan masalah yang dihadapinya, agar tercapai kemampuan untuk memahami dirinya (self understanding), kemampuan untuk menerima dirinya (self acceptance), kemampuan untuk mengarahkan dirinya (self direction), dan kemampuan untuk merealisasikan dirinya (self realization) sesuai dengan potensi atau kemampuannya dalam mencapai penyesuaian diri dengan lingkungan, baik keluarga, sekolah maupun masyarakat.

Pendapat-pendapat yang dikemukakan di atas dapat diartikan bahwa bimbingan, yaitu:

a. Bimbingan merupakan suatu proses yang terus menerus.

b. Bimbingan merupakan suatu proses membantu individu.

c. Bantuan yang diberikan adalah bantuan psikologis agar individu dapat mengernbangkan dirinya secara maksimal sesuai dengan potensi atau kemampuannya.

d. Tujuan utama bimbingan adalah agar individu dapat menyesuaikan diri dengan lingkungannya.

e. Bimbingan diberikan oleh orang-orang yang ahli, yaitu orang-orang yang memiliki kepribadian yang terpilih dan telah memperoleh pendidikan serta latihan yang memadai dalam bidang bimbingan dan konseling.
Bimbingan secara luas ialah suatu proses pemberian hantuan yang terus menerus dan sistematis oleh seorang ahli kepada individu dalarn memecahkan masalah yang dihadapinya agar tercapai, kemampuan untuk dapat memahami dirinya, kemampuan untuk mengarahkan dirinya dan kemampuan untuk merealisasikan dirinya, sesuai dengan potensi yang dimilikinya, kemampuannya dalam penyesuaian diri dengan lingkungannya, baik di dalam keluarga, sekolah, maupun masyarakat.

\section{Pengertian Konseling}

Konseling adalah hubungan timbal balik antara konselor dan konseli yang dilakukan secara tatap muka dan sadar dalam memecahkan suatu masalah, dan diharapkan konseli dapat mengatasi masalah tersebut dengan potensi yang ada pada dirinya. Seperti halnya dengan bimbingan, untuk mendapat pengertian yang lebih jelas, di bawah ini dikutip beberapa definisi konseling, di antaranya sebagai berikut: Menurut Winkel yang dikutip oleh Hamdani konseling didefinisikan sebagai "serangkaian kegiatan paling pokok dari bimbingan dalam usaha membantu konseli/klien secara tatap muka dengan tujuan agarkonseli/klien dapat mengambil tanggung jawab sendiri terhadap berbagai persoalan atau masalah khusus. Prayitno dan Erman Amti (2004 :101) menyatakan bahwa Konseling adalah hubungan pribadi yang dilakukan secara tatap muka antara dua orang dalam mana konselor melalui hubungar. itu dengan kcmampuan-kemampuan khusus yang dimilikinya, menyediakan situasi belajar.

Dalam hal ini, konseli dibantu untuk memahami diri sendiri, keadaannya sekarang, dan kemungkinan keadaan masa depan yang dapat ia ciptakan dengan menggunakan potensi yang dimilikinya, demi untuk kesejahteraan pribadi maupun masyarakat. Pendapat-pendapat yang dikemukakan di atas dapat diartikan bahwa konseling adalah teknik pelayanan dalam bimbingan yang dilakukan oleh dua orang atau lebih secara tatap muka untuk membantu menyelesaikan atau memecahkan masalahnya agar klien mampu memperoleh keputusan-keputusan yang memuaskan. Bimbingan dan Konseling mempunyai hubungan yang erat, yang keduanya saling rnelengkapi dalam membantu/konseli/klien atau orang lain dalam memecahkan permasalahan dan mengubah pola hidup seseorang. 


\section{Kualifikasi dan Persyaratan Guru Bimbingan dan Konseling}

Guru Bimbingan dan Konseling (BK) sekolah haruslah memenuhi kriteria atau persyaratan tertentu. selain memenuhi persyaratan tertentu, guru BK dituntun pula memiliki kompetensi personal, dan kompetensi sosial yang baik. Sosok utuh kompetensi tersebut menjiwai aktivitasnya dalam bekerja membantu siswa atau klien dalam tugas-tugas perkembangannya mencapai perkembangan yang optimal, sehingga ketiga kompetensi yang dimiliki terintegrasi dalam jiwa profesinya sebagai helper.Guru bimbingan dan Konseling harus memiliki persyaratan tertentu, diantara persyaratan pendidikan, kepribadian, keterampilan dan pengalaman-pengalaman khusus dengan uraian sebagai berikut:

a. Persyaratan pendidikan yang harus dipenuhi guru pembimbing idealnya seorang sarjana pendidikan jurusan Psikologi Pendidikan Bimbingan dan Konseling yang sudah memiliki sertifikat konselor, seorang guru tenaga pengajar yang sudah mengikuti penataran mengenai bimbingan dan konseling dengan memperoleh sertifikat kbusus di bidang bimbingan dan konseling.

b. Persyaratan pribadi, yaitu sifat-sifat yang baik, memiliki minat yang mendalam untuk dapat bekerjasama dengan orang lain, dan kematangan emosi. kesabaran, keramahan, keseimbangan batin, tidak leas menarik diri dan situasi yang terhadap kritik, dan memiliki rasa humor.

c. Persyaratan pengalaman, seorang guru relawan, cepat tanggap, pembimbing yang professional hendaknya memiliki pengalaman mengajar atau melaksanakan praktik membimbing selama dua tahun, ditambah satu tabun pengalarnan praktik konseling.

Menurut W.S Winkle (2004 : 14) kualifikasi guru Bimbingan dan Konseling adalah : Seseorang yang diangkat dari bidang studi Bimbingan dan Konseling merupakan tenaga generalis dalarn arti memberikan lebih dari satu layanan bimbingan dan menaruh perhatian pada perkembangan siswa. Tugas seorang guru pembimbing tidak hanya menyampaikan ilmu-ilmu pengetahuan tetapi juga menanamkan nilai-nilai dan sikap mental serta melatih berbagai keterampilan dalam usaha mengantarkan peserta didiknya ke arah kedewasaan jasmani dan rohani. Guru pembimbing merupakan tugas profesional yang kompeten dalam bidang bimbingan dan . penyuluhan dengan sebaik-baiknya.

\section{Layanan Pokok dalam Bimbingan dan Konseling di Sekolah}

Layanan bimbingan dan konseling sangat dibutuhkan agar siswa yang mempunyai masalah dapat dibantu, dan mereka dapat lebih mengenal diri mereka. Secara khusus, pelayanan bimbingan dan konseling di sekolah bertujuan membantu siswa agar dapat mencapai tujuan perkembangan kepribadian yang meliputi aspek pribadi, sosial, belajar dan karier. Bimbingan pribadi-sosial dimaksudkan untuk mencapai tujuan dan tugas perkembangan pribadi sosial dalam mewujudkan pribadi yang takwa, mandiri dan bertanggung jawab.

Menurut Sartono dan Umar (1998: 12) mengemukakan bahwa tujuan konseling adalah: Membantu konseli/klien memperoleh informasi dan kejelasan emosi dan ciri kepribadiannya yang bisa mengganggu pengambilan keputusan. Dengan konselingkonseli/ klien dibantu memperoleh pemahaman bukan saja mengenai kemampuan, minat dan kesempatan yang ada melainkan juga mengenai emosi dan sikap yang bisa mempengaruhi dalam menentukan pilihan dan pengambilan keputusan. Konseling juga bertujuan membantu seseorang belajar mengenai keseluruhan dari proses pengambilan keputusan, sehingga pada akhimya ia bisa melakukan sendiri. Sedangkan menurut Syamsu Yusuf (2006:35) tujuan bimbingan dan konseling di sekolah adalah:

a. Membantu siswa merencanakan kegiatan penyelesaian studi, perkembangan karier serta kehidupanya dimasa yang akan datang

b. Mengembangkan seluruh potensi dan kekuatan yang dimilikinya seoptimal mungkin

c. Menyesuaikan diri dengan linglrungan masyarakat serta lingkungan kerjanya

d. Mengatasi hambatan dan kesulitan yang dihadapi dalam studi, penyesuaian dengan lingkungan pendidikan, masyarakat, maupun lingkungan kerja.

Dari pendapat-pendapat di atas dapat disimpulkan bahwa tujuan bimbingan dan konseling di sekolah yaitu membantu siswa mengatasi kesulitan belajar, mengatasi hubungan sosial, mengatasi kesulitan yang berkaitan dengan emosi dan sikap yang bisa 
mempengaruhi dalam menentukan pilihan dan pengambilan keputusan. Memaharni dan mengatasi kesulitan- kesulitan sendiri menggunakan kemampuanya untuk kepentingan dirinya, kepentingan lernbaga dan masyarakat. Menyesuaikan diri dengan keadaan dan tuntutan dari lingkungannya dan mengernbangkan segala potensi dan kekuatan yang dirnilikinya secara tepat dan teratur Layanan birnbingan tidak hanya berfungsi sebagai penunjang kegiatan pernbelajaran, tapi juga sebagai proses layanan konseling yang comprehensive yang berkaitan erat dengan seluruh proses pendidikan dan proses pernbelajaran paripurna

\section{Definisi Kecemasan Menurut Para Ahli}

Kecemasan dalam Kamus Bahasa Indonesia adalah merasa sangat gelisah, takut dan kbawatir. Kecemasan dalam kamus bahasa lnggrisnya anxiety berasal dari bahasa latin angustus yang berarti kaku, dan ango, anci yang berarti mencekik. Kecemasan adalah suatu keadaan khawatir yang mengeluh bahwa sesuatu yang buruk akan segera terjadi. Definisi Kecemasan dikutif dari http:aprilliagustina.blogspot.com/2012 menurut beberapa para ahli:

a. Zakiah Daradjat dalam buku nya (1990:45): Kecemasan adalah manifestasi dari berbagai proses emosi yang bercampur baur, yang teIjadi ketika orang sedang mengalami tekanan perasaan (frustasi) dan pertentangan batin (konflik).

b. Sigmund Freud (dalam Alwisol, 2005:28) menyatakan, kecemasan adalah fungsi ego untuk memperingatkan individu tentang kemungkinan datangnya suatu bahaya sehingga dapat disiapkan reaksi adaptif yang sesuai. Kecemasan berfungsi sebagai mekanisme yang melindungi ego karena kecemasan member sinyal kepada kita bahwa ada bahaya dan kalau tidak dilakukan tindakan yang tepat maka bahaya itu meningkat sampai ego dikalahkan.

c. Atikson mengatakan : kecemasan adalah emosi tidak menyenangkan yang ditandai dengan istilah-istilah seperti khawatir dan rasa takut yang kadang- kadang kita alami dalam tingkah laku berbeda-beda.

d. Menurut Post (1978), kecemasan adalah kondisi emosional yang tidak menyenangkan, yang ditandai oleh perasaan -perasaan subjektif seperti ketegangan, ketakutan, kekhawatiran dan juga ditandai dengan aktifnya system syaraf pusat.

e. Lefrancois (1980), kecemasan merupakan reaksi emosi yang tidak menyenangkan, yang ditandai dengan ketakutan

f. Kartono (1981) mengungkapkan bahwa neurosa kecemasan ialah kondisi psikis dalam ketakutan dan kecemasan yang kronis, sungguhpun tidak ada rangsangan yang spesifik.

g. Wignyosoebroto (1981), ada perbedaan mendasar antara kecemasan dan ketakutan, pada ketakutan apa yang menjadi sumber penyebabnya selalu dapat ditunjuk secara nyata, sedangkan pada kecemasan sumber penyebabnya tidak dapat ditunjuk dengan tegas, jelas dan tepat.

h. Navid (2005), kecemasan dapata menjadi reaksi emosional yang normal dibeberapa situasi, tetapi tidak disituasi lain.

i. Hembree (1988), kecemasan menghadapi ujian (test anxiety), ini masalah pertama yang kerap menyebabkan anak-anak cerdas tak berdaya menghadapi soal ujian yang paling mudah sekalipun. Ibarat kaki, kecemasan menghadapi ujian membuat anak-anak lumpuh tak berdaya.

Pada kadar tertentu, kecemasan bermanfaat meningkatkan gairah dan kesungguhan belajar anak sehingga ujian terasa begitu menantang bukan menakutkan. Kecemasan pada tingkat ini justru meningkatkan prestasi siswa, ini berarti guru maupun orang tua bertugas menjaga kadar kecemasan anak agar tidak melebihi ambang batas. Tetapi bagaimana mungkin guru dan orangtua mampu menjalankan tugas tersebut jika mereka memandang ujian nasional tertalu penting, sebegitu pentingnya, sampai-sampai mereka sendiri menghadapi kecemasan yang jauh lebih menakutkan dibanding anakanak.Dengan demikian penulis dapat menarik kesimpulan bahwa kecemasan adalah kondisi emosional yang tidak menyenangkan, yang ditandai oleh perasaanperasaan subjektif seperti ketegangan, ketakutan, kekhawatiran dan ditandai dengan aktifnya sistem syaraf pusat.

\section{Gejala-Gejala Kecemasan}

Cemas mempunyai penampilan atau gejala yang bermacam-macam antara lain :

a. Gejala jasmaniah (Fisiologis) yailu ujungujung anggota dingin (kaki dan tangan), 
keringat berpcikan, gangguan pencernaan detak jantung cepat, tidur terganggu, kepala pusing, hilang nafsu makan dan fernafasan terganggu.

b. Gejala kejiwaan antara lain sangat takut, merasa akan terjadi bahaya atau penyakit, tidak mampu memusatkan perhatian. selalu merasa akan terjadi kesuraman, kelemahan dan kemurungan, hilang kepercayaan dan ketenangan, dan ingin lari dan menghadapi suasana kehidupan.

\section{Sebab - Sebab Kecemasan}

Menurut Karen Horney, bahwa kecemasan disebabkan oleh tiga unsur yaitu tidak berdaya, rasa permusuhan dan rasa menyendiri, faktor-faktor tersebut timbul sebagai berikut:

a. Tidak adanya suasana kehangatan dan keharmonisan dalam keluarga dan perasaan anak bahwa ia adalah anak yang ditolak, tidak disayangi dan tidak dikasihi, disamping itu merasa mahluk lemah ditengah-tengah alam permusuhan

b. Memperlakukan anak tidak adil secara proporsional dan kasih sayang serta perhatian rasa simpati dan empathy terhadap anak

c. Terjadinya kecemasan karena lingkungan yang penuh dengan bermacam-macam ancaman dan halangan, semuanya itu menyebabkan merasa hidup dalam alam penuh pertentangan.

\section{Solusi Mengatasi Kecemasan}

Bermacam cara yang dapat dilakukan untukmengatasi perasaan tertekan, pertentangan batin dan kecemasan itu, perasaan -perasaan seperti itu sangat mengurangi rasa nyaman dan bahagia sehingga kadang-kadang orang terdorong melakukan sesuatu untuk menghilangkan sebab-sebabnya, tetapi tidak semua orang sanggup mengatasinya dengan cara tersebut, dan mencari jalan lain yang kurang sehat yaitu berupa usaha-usaha yang tidak disadari , cara-cara tersebut antara lain :

a. Pembelaan yaitu usaha yang dilakukan untuk mencari alasan-alasan yang masuk akal bagi tindakan yang sesungguhnya tidak masuk akal, dinamakan pembelaan. Pembelaan ini tidak dimaksudkan agar tindakan yang tidak masuk akal itu dijadikan masuk akal.

b. Proyeksi yaitu menimpakan sesuatu yang terasa dalam dirinya kepada orang lain, terutama tindakan, fikiran atau dorongandorongan yang tidak masuk akal

c. Identifikasi yaitu kebalikan dari proyeksi. di mana orang turut merasakan sebagian dari tindakan atau sukses yang dicapai oleh orang lain. Apabila ia melihat orang berhasil dalam usahanya ia gembira seolah-olah ia yang sukses, dan apabila ia melihat orang kecewa ia juga ikut merasa sedih.

d. Hilang hubungan (disassosiasi) yaitu apabila orang merasa bahwa ada seseorang yang dengan sengaja menyinggung perasaannya, maka ia akan marah dan menghadapinya dengan balasan yang sama. Dalam hal ini perasaan, fikiran dan tindakannya adalah saling berhubungan dengan harmonis. Akan tetapi keharmonisan itu mungkin hilang akibat pengalaman-pengalaman pahit yang dilalui waktu kecil.

e. Represi adalah tekanan untuk melupakan hal-hal, dan keinginan-keinginan yang tidak disetujui oleh hati nuraninya. Semacarn usaha untuk memelihara diri supaya jangan merasaadanya dorongan-dorongan yang tidak sesuai dengan hatinya.

f. Subtitusi yaitu cara pembelaan diri yang paling baik di antara cara-cara yang tidak di sadari dalam menghadapi kesukaran. Da!arn subtitusi orang melakukan sesuatu, karena tujuan-tujuan yang baik, yang berbeda sama sekali dari tujuan yang mudah dapat diterima, dan berusaha mencapai sukses. Subtitusi itu ada dua macam. yaitu :

- Sublimasi, pengungkapan dari dorongan yang tidak dapat diterima dalam masyarakat dengan cara yang dapat diterima. Misalnya. orang yang tidak dapat memenuhi dorongan seksuilnya dengan cara yang wajar. mencari cara pengganti (sublimasi) yang memuaskan juga, misalnya mengarang sajak dan cerita, membuat lukisan-tukisan dan sebagainya.

- Kompensasi, usaha untuk: mencapai sukses dalarn suatU lapangan, setelah gagal dalam lapangan lain. Misalnya seorang anak yang tidak biasa berolah raga, akan bersungguh sungguh sekali dalam pelajaran, sehingga ia menjadi murid yang terpandai dalam kelasnya, dan menjadi pusat perhatian guru dan 
kawan-kawannya, demikian juga sebaliknya

\section{Upaya Guru Bimbingan dan Konseling dalam Mengatasi Kecemasan}

a. Tugas dan Tanggung Jawab Guru Bimbingan dan Konseling

Dalam menjalankan tugasnya sebagai pendidik guru bimbingan dan konseling dituntut kemampuannya untuk mampu mengenali sikap dan prilakn siswa. Untuk keterampilan ini dibutuhkan pemahaman yang mendalarn pada ilmu psikologi tentang tahapan pertumbuhan perkembangan khususnya anak usia remaja, serrta dapat menafsirkan kecenderungan-kecenderungan yang ditampilkan peserta didik dalarn proses belajar di sekolah. Kesuksesan melalui tahapan-tahapan pertumbuhan dan perkembangan merupakan dasar kesuksesan mencapai perkembangan tahap berikutnya. Oleh karena hal tersebut maks menjadi tanggung jawab guru bimbingan dan konseling agar siswa tidak mengalarni hambatan dalam proses pertumbuhan dan perkembangannya.

b. Tugas dan tanggung jawab guru Bimbingan dan Konseling dalam. SKB Mendikbud dan kepala BAKN no. 043311993 dan no 25 tahun 1995 pasal menyebutkan: Guru pembimbing adalah guru yang mempunyai tugas. tanggung jawab dan hak secara penuh dalam kegiatan bimbingan dan konselirig Berpijak dari keberagaman perilaku siswa dibutuhkan konselor yang arif. memiliki empati yang tinggi terhadap masalah siswa, dapat membuka diri, mampu menjadi motivator, pendengar dan sahabat curhatnya siswa.

\section{METODE PENELITIAN}

Metode penelitian yang digunakan dalam penelitian ini adalah metode kualitatif dengan pendekatan deskriptif. Alasan menggunakan metode ini dikarenakan metode kualitatif memiliki wawasan yang luas dan mendalam tentang bidang bimbingan dan konseling dalam mengatasi kecemasan siswa menghadapi ujian nasional yang akan diteliti dan dapat menciptakan rapport. Sedangkan penulisan ini dilakukan dengan menggunakan metode deskriptif,tujuannya adalah untuk menggambarkan sasaran serta mengefisienkan secara sistematis, mengenai fakta-fakta yang faktual maupun yang aktual serta hubungan antara fenomena yang diteliti. Pengumpulan data dilakkukan dengan menggunakan data prmer dengan metode observasi. Metode observasi adalah metode yang dipergunakan dalam penelitian, dimana peneliti mengajukan apertanyaan (angket) untuk kemudian dianalisis. Jadi dalam hal ini, peneliti menggunakan alat pengumpul data (instrument) nya adalah daftar pertanyaan dalam angket.

Pengambilan sampel untuk penelitian deskriptif, jika populasinya diatas 1000 , sampel sekitar 10\% sudah cukup, tetapi jika populasinya sekitar 100 , sampelnya paling sedikit 30\%. Dalam penelitian ini peneliti mengambil sampel 124 siswa kelas XII IPA dan XII IPS yang diambil secara random (acak). Penelitian ini dilakukan di Sekolah Menengah Atas (SMA) Nusantara I Kota Tangerang waktu penelitian dilaksanakan pada bulan Juni sampai dengan bulan September 2016, adapun teknik analisis data yang digunakan oleh peneliti adalah metode deskriptif-kualitatif, dan instrumen penelitian melalui angket, wawancara dan observasi tujuan dari metode ini adalah untuk menyederhanakan data sehingga dapat dimengerti. Data yang diperoleh melalui alat pengumpul data dianalisis. Khusus data yang diperoleh melalui angket dianalisis dengan cara sebagai berikut.

Data jawaban yang telah dikumpulkan dihitung frekuensinya sesuai jenisnya ke dalam tabulasi pengelompokkan data (Tabel A) Selanjutnya data tersebut satu persatu dipersentasekan, hasilnya dimasukan ke dalam tabel persentase data (Tabel B), dengan menggunakan cara yaitu jumlah jawaban siswa pada masing-masing pertanyaan yang diajukan dalam angket dibagi jumlah siswa sebagai sumber data dikali 100 persen, yang dapat dirumuskan sebagai berikut.

$$
\begin{gathered}
\mathrm{P}=\mathrm{fj} \\
\mathrm{-} \mathrm{n}
\end{gathered} \mathrm{x} \mathrm{100 \%}
$$

Keterangan:

$\mathrm{P}=$ Persentase yang dicari, $\mathrm{fj}=$ Frekuensi jawaban siswa sebagai sumber data, $\mathrm{n}=$ Jumlah siswa sebagai sumber data. Hasil perhitungan yang berupa nilai persentase, dianalisis kemudian diinterpretasikan dengan berpedoman kepada rentang skala gradasi sebagai berikut: $85 \%-100 \%$ = amat baik, $80 \%$ $-85 \%$ = baik, $70 \%-80 \%$ = cukup, $70 \%$ ke 
bawah $=$ kurang. Hasil interpretasi data tersebut merupakan tafsiran jawaban atas pertanyaan yang diajukan dalam angket yang secara keseluruhan merupakan bahan kesimpulan penelitian. Arikanto,Siharsini (1996: 65).

\section{HASIL PENELITIAN DAN PEMBAHASAN}

Berdasarkan hasil pengolahan data yang telah dijabarkan ke dalam Tabel A Tabulasi pengelompokan data dan Tabel B Tabulasi persentase data selanjutnya hasil pengolahan data tersebut satu per satu diinterpretasikan dengan berpedoman pada ukuran rentang skala gradasi yang telah ditetapkan seperti tersebut diatas, kemudian berdasarkan Tabel C Interpretasi data dilaksanakan mulai dari pertanyaan nomor 1 sampai 25 , dengan $(n=$ 124) Selanjutnya untuk kepentingan analisis data secara kualitatif, maka dibuat perhitungan jawaban per item, data yang telah dikumpulkan digunakan untuk menganalisa terhadap teori teori yang dijadikan dasar pengukuran dengan menggunakan deskriptif kumulatif, yaitu melakuakn penyebaran angket terstruktur yang jawabannya sudah ditentukan.

Dari hasil penelitian di atas, dapat didefinisikan sebagai berikut, pertanyaan pertama yang diajukan kepada siswa siswi, sebagai berikut:

a. Apakah Anda mendapatkan informasi tentang pentingnya layanan bimbingan dan konseling di sekolah? Interpretasi : Berdasarkan hasil pengolahan data diketahui hahwa siswa yang menjawab selalu frekuensi 102 : $82.3 \%$. yang menjawab sering frekuensi $19: 15,3 \%$, yang menjawab kadang-kadang frekuensi 3: 2,4\%, dan yang menjawab jarang0\% (butir ini kategori Baik ) berikutnya: Apakah anda mendapatkan bimbingan dalam meningkatkan semangat belajar agar bisa lulus ujian nasioanal? Interpretasi : Berdasarkan hasil pengolahan data diketahui hahwa siswa yang menjawab selalu 86,29\%, yang menjawab sering $13,70 \%$ yang menjawab kadang-kadang $0 \%$ $\mathrm{s}$ dan yang menjawab jarang $0 \%$. Dari data tersebut dapat di interpretasikan bahwa siswa mendapatkan bimbingan dalam meningkatkan semangat belajar agar lulus Ujian Akhir Nasioanl. (butir ini termasuk dalam kategori Baik ) selanjutnya.

b. Apakah anda mendapatkan layanan bimbingan dan konseling secara terjadwal?
Interpretasi: Berdasarkan hasil pengolahan data diketahui bahwa siswa yang menjawab selalu $88,70 \%$ yang menjawab sering $9,7 \%$, siswa yang menjawab kadang-kadang1,6\% siswa yang menjawab jarang sebesar $0 \%$. Dari data tersebut dapat di interpretasikan bahwa siswa mendapatkan layanan bimbingan dan konseling secara terjadwal. (butir ini kategori Baik) selanjutnya:

c. Apakah anda mendapatkan bimbingan tentang penggunaan waktu belajar yang baik dan efisien ? Interpretasi : Berdasarkan hasil pengolahan data diketahui bahwa siswa yang menjawab selalu $76,6 \%$ a yang menjawab sering $15,3 \%$ siswa yang menjawab kadangkadang $6,5 \%$ siswa yang menjawab jarang $1,6 \%$ Dari data tersebut dapat eli interpretasikan bahwa siswa mendapat:kkn bimbingan tentang penggunaan waktu belajar yang baik dan efisien (Butir ini kategori Baik ) selanjutnya

d. Apakah anda mendapatkan informasi untuk memilih ternan yang baik dalam pergaulannya ? Interpretasi : Berdasarkan hasil pengolahan data diketahui bahwa siswa yang menjawab selalu $74,2 \%$, siswa yang menjawab sering $23,4 \%$, siswa yang rnenjawab kadang-kadang $1,6 \%$, siswa yang menjawab $0,8 \%$. Dari data tersebut dapat di interpretasikan bahwa siswa mendapatkan pengarahan tentang memilih ternan yang baik (butir ini kategori Cukup) selanjutnya:

e. Apakah anda mendapatkan informasi tentang pentingnya motivasi belajar dalam menghadapi ujian nasional? Interpretasi : Berdasarkan hasil pengolahan data diketahui bahwa siswa yang menjawab selalu $87,1 \%$, siswa yang rnenjawab sering $11,3 \%$, siswa yang menjawab kadang-kadang $1,6 \%$, siswa yang menjawab jarang sebesar $2 \%$ Dari data tersebut dapat di interpretasikan bahwa siswa mendapatkan informasi tentang pentingnya motivasi dalam menghadapi ujian nasional (butir ini kategori Baik).

f. Apakah anda mendapatkan bimbingan agar siap menghadapi Ujian Nasional? Interpretasi : Berdasarkan hasil pengolahan data diketahui hahwa siswa yang menjawab selalu $86,3 \%$, siswa yang menjawab sering $11,3 \%$, siswa yang menjawab kadangkadang sehesar $1,6 \%$, siswa yang menjawab jarang $0,8 \%$. Dari data tersebut dapat di interpretasikan bahwa siswa mendapatkan bimbingan agar siap menghadapi ujian nasional (butir ini kategori Baik) 
g. Apakah anda mendapatkan layanan dalam mengatasi kecemasan menghadapi ujian nasional ? Interpretasi : Berdasarkan hasil pengolahan data diketahui hahwa siswa yang menjawab selalu 79\%, siswa yang menjawab sering $19,4 \%$, siswa yang menjawab kadang-kadang $0,8 \%$, siswa yang menjawab jarang $0,8 \%$. Dari data tersebut dapat di interpretasikan bahwa siswa mendapatkan layanan dalam mengatasi kecemasan menghadapi ujian nasional. (butir ini kategori Baik).

h. Apakah anda mendapatkan bimbingan dalam mengikuti kegiatan try out ujian nasional di sekolah? Interpretasi : Berdasarkan hasil pengolahan data diketahui bahwa siswa yang menjawab selalu $44,4 \%$, siswa yang menjawab sering $27,4 \%$, siswa yang menjawab kadang-kadang 28,2\%, siswa yang menjawab jarang $0 \%$. Dari data tersebut dapat di interpretasikan bahwa siswa mendapatkan bimbingan dalam mengikuti kegiatan Try out ujian nasional di sekolah (butir ini kategori Sedang)

i. Apakah anda menciapatkan infonnasi tentang dampak dad tidak lulus ujian nasioanal? nterpretasi : Berdasarkan hasil pengolahan data diketahui bahwa siswa yang menjawab selalu 88,7\%, siswa yang menjawab sering $11,3 \%$, siswa yang menjawab kadang-kadang 0 , siswa yang menjawab jarang sebesar 0 . Dari data tersebut dapat di interpretasikan bahwa siswa mendapatkan informasi tentang tentang dampak dari tidak lulus ujian nasioanal. (butir ini kategori Baik).

j. Apakah anda mendapatkan informasi tentang pentingnya mematuhi tata tertib yang ada di sekolah ? Interpretasi : Berdasarkan hasil pengolahan data diketahui bahwa siswa yang menjawab seialu 91,9\%, siswa yang rnenjawab sering $8,1 \%$, siswa yang menjawab kadang-kadang 0 , siswa yang menjawab jarang 0 Dan data tersehut dapat di interpretasikan bahwa siswa mendapatkan informasi tentang tentang pentingnya mematuhi tata tertib yang ada di sekolah (butir ini kategori Baik).

k. Apakah anda mendapatkan konseling jika mendapatkan nilai basil belajar yang rendah? Interpretasi Berdasarkan hasil pengolahan data diketahui bahwa siswa yang menjawab seialu $71,8 \%$ siswa yang menjawab sering $20.1 \%$, siswa yang rnenjawab kadang kadang 6,5\%, siswa yang menjawab jarang 1,6\% Dari data tersehut dapat di interpretasikan bahwa siswa mendapatkan informasi tentang tentang pentingnya mematuhi tata tertib yang ada di sekolah (butir ini kategori cukup).

1. Apakah anda mendapatkan layanan konseling dalam memhantu mengatasi masalah kecernasan siswa menghadapi ujian nasional, bekerja sarna dengan guru bidang studi? Berdasarkan hasil pengolahan data diketahui bahwa siswa yang menjawab selalu $87,9 \%$, siswa yang rnenjawab sering $12,1 \%$, siswa yang menjawab kadangkadang 0, siswa yang menjawab jarang 0 Dan data tersebut dapat di interpretasikan bahwa siswa mendapatkan informasi tentang tentang pentingnya mematuhi tata tertib yang ada di sekolah (butir ini kategori Baik).

m. Apakah anda mendapatkan bimbingan kesulitan belajar dalam mempersiapkan ujian nasional? Interpretasi : Berdasarkan hasil pengolahan data diketahui bahwa siswa yang menjawab sela!u $87.1 \%$, siswa yang menjawab sering $11,3 \%$, siswa yang menjawab kadang-kadang $0,80 \%$, siswa yang menjawab jarang $0,80 \%$. Dari data tersehut dapat di interpretasikan bahwa siswa mendapatkan bimbingan kesulitan belajar dalam mempersiapkan ujian nasional (butir ini termasuk Baik)

n. Apakah anda mendapatkan tambahan waktu belajar bempa pendalaman materi oleh guru bidang studi yang tennasuk: pelajaran yang di ujian nasionalkan? Interpretasi : Berdasarkan hasil pengolahan data diketahui bahwa siswa yang menjawab selalu $79,1 \%$, siswa yang menjawab sering $12,9 \%$, siswa yang menjawab kadang-kadang 5,6\%, siswa yang menjawab jarang 2,4\%. Dari data tersebut dapat di interpretasikan bahwa siswa mendapatkan informasi tentang bagaimana menwnbuhkan minat belajar. (butir ini Baik)

o. Apakah anda mendapatkan informasi tentang pentingnya tekun belajar dan membaca buku-buku pelajara? Interpretasi : Berdasarkan hasil pengolahan data diketahui bahwa siswa yang menjawab selalu 59,7\%, siswa yang menjawab sering $21,7 \%$, siswa yang menjawab kadang-kadang $9,7 \%$, siswa yang menjawab jarang $8,9 \%$, Dari data tersebut dapat di interpretasikan bahwa siswa mendapatkan informasi tentang pentingnya tekun belajar dan membaca 
buku-buku pelajaran (butir ini kategori Cukup)

p. Apakah anda mendapatkan layanan bimbingan individual dan kelompok untuk membantu masalah kecemasan menghadapi ujian nasioanal ? Interpretasi: Berdasarkan hasil pengolahan data diketahui bahwa siswa yang menjawab selalu $87,9 \%$, siswa yang menjawab sering $12.1 \%$, siswa yang menjawab kadang-kadang 0 , siswa yang menjawab jarang 0. Dan data tersebut dapat di interpretasikan bahwa siswa mendapatkan layanan bimbingan individual dan kelompok untuk. membantu masalah kecemasanmenghadapi ujian nasioanaL (butir ini termasuk Baik)

q. Apakah anda mendapatkan konseling jika merasakan kesulitan belajar siswa? Interpretasi : Berdasarkan hasil pengolahan data diketahui bahwa siswa yang menjawab selalu $84,7 \%$, siswa yang menjawab sering sebesar $12,9 \%$, siswa yang menjawab kadang-kadang $1,6 \%$, siswa yang menjawab jarang $0,8 \%$. Dari data tersebut dapat di interpretasikan bahwa siswa mendapatkan konseling jika merasakan kesulitan belajar siswa (butir ini kalegori Baik)

r. Apakah anda mendapatkan konseling jika mengalami kegelisahan pribadi ? Interpretasi : Berdasarkan hasil pengolahan data diketahui bahwa siswa yang menjawab selalu $59,7 \%$, siswa yang menjawab sering $30,6 \%$, siswa yang menjawab kadangkadang $9,7 \%$, siswa yang menjawab jarang 0 . Dari data tersebut dapat di interpretasikan bahwa siswa mendapat.kan konseling jika mengalami kegelisahan pribadi . (butir ini termasuk Cukup).

s. Apakah anda mendapatkan informasi tentang pentingnya lnterpretasi : Berdasarkan hasil pengolahan data diketahui bahwa siswa yang menjawab selalu $86,3 \%$, siswa yang menjawab sering $13,7 \%$, siswa yang menjawab kadang-kadang 0\%, siswa yang menjawab jarang $0 . \%$ Dari data tersehut clapat di interpretasikan hahwa siswa mendapatkan informasi tentang pentingnya bakat, minat serta kemampuan dalam belajar (butir ini kategori baik ).

t. Apakah anda rnendapatkan informasi tentang pentingnya melakukan pengulangan pelajaran yang diterima di sekolah untuk dipelajari di rumah? Interpretasi : Berdasarkan hasil pengolahan data diketahui bahwa siswa yang menjawab selalu $87,9 \%$, siswa yang menjawab sering $12,1 \%$, siswa yang menjawab kadang-kadang $0 \%$ siswa yang menjawab jarang $0 \%$. Dari data tersebut dapat di interpretasikan bahwa siswa mendapatkan infonnasi tentang pentingnya melakukan pengulangan pelajaran yang diterima di sekolah untuk dipelajari di rumah (butir ini kategori Baik ).

u. Apakah anda merasa kesulitan belajar yang anda alami berkurang setelah memperoieh layanan birnbingan dan konseling ? Interpretasi Berdasarkan hasil pengolahan data diketahui bahwa siswa yang menjawab selalu sebesar $61,3 \%$, siswa yang menjawab sering 20,2\%, siswa yang menjawab kadang-kadang $10,5 \%$, siswa yang menjawab jarang $8,1 \%$ Dari data tersehut dapat di interpretasikan bahwa siswa mendapatkan informasi layanan dalam memperoleh kesulitan (butir ini kategori cukup)

v. Apakah anda mendapatkan informasi untuk: rajinn mengikuti kegiatan keagamaan haik di lingkungan rumah maupun di lingkungan sekolah ? Interpretasi Berdasarkan hasil pengolahan data diketahui bahwa siswa yang menjawab selalu $88,7 \%$, siswa yang menjawab sering sebesar $11,3 \%$, siswa yang menjawab kadang-kadang 0\%, siswa yang menjawab jarang sebesar 0\%. Dari data tersebut dapat di interpretasikan bahwa siswa mendapatkan informasi untuk rajin mengikuti kegiatan keagamaan baik di lingkungan rumah maupun di lingkungan sekolah. (butir ini kategori Baik ).

w. Apakah anda mendapatkan bimbingan tentang hal-hal yang dapat digunakan dalam mengatasi kesulitan belajar siswa? Interpretasl . Berdasarkan hasil pengolahan data diketahui bahwa siswa yang menjawab selalu $79, \%$, siswa yang rnenjawab sering $12,9 \%$, siswa yang menjawab kadangkadang $8.1 \%$. siswa yang menjawab jarang sebesar \%. Dari data tersebut dapat di interpretasikan bahwa siswa mendapatkan infonnasi bimbingantentang hal-hal yang dapat digunakan dalam mengatasi kesulitan belajar siswa (butir ini kategori Baik).

x. Apakah anda mendapatkan layanan kesulitan belajar? Interpretasi : Berdasarkan hasil pengolahan data diketahui bahwa siswa yang menjawab selalu $87,1 \%$, siswa yang menjawab sering $11,3 \%$, siswa yang menjawab kadang-kadang 1,6\% siswa yang menjawab jarang $0 \%$. Dari data tersebut 
dapat di interpretasikan bahwa siswa mendapatkan layanan kesulitan belajar. (butir ini kategori Baik) Hasil interpretasi data secara keseluruhan setelah diketahui, selanjutnya dikelompokkan ke dalam tabulasi hasil interpretasi data (tabel C) sebagai berikut kategori sedang $4 \%$, kategori cukup 20\% dan kategori baik $76 \%$

\section{SIMPULAN DAN SARAN}

\section{Simpulan}

Berdasarkan hasil penelitian yang penulis lakukan di sekolah yang berupa hasil angket, hasil wawancara, dan hasil observasi, tentang peranan guru bimbingan dan konseling dalam mengurangi kecemasan siswa Kelas XII menjelang Ujian Akhir nasional dilingkungan SMA Nusantara I Tangerang penulis dapat mengemukakan beberapa simpulan, sebagai berikut :

1. Guru bimbingan dan konseling selalu rnengarahkan siswa untuk mengatasi kecemasan siswa dalam rnenghadapi ujian akhir nasional

2. Guru bimbingan dan konseling berusaha mengatasi kesulitan belajar siswa dalam menghadapi Ujian Nasional.

3. Guru bimbingan dan konseling berusaha memotivasi siswa dalam menghadapi Ujian Nasional agar siap mental

4. Guru bimbingan dan konseling berusaha membantu siswa agar dapat belajar efektif dan efisien

5. Guru bimbingan konseling berusaha mengatasi kegelisan pribadi siswa Beberapa temuan yang perlu mendapat perhatian lebih intens dari semua pihak adalah berdasarkan tabel pertanyaan (No. 9. No. 12. No. 16. No. 19. No. 22) masih termasuk kategori sedang dan cukup

\section{Saran}

Berdasarkan kesimpulan peneliti yang telah dikemukakan diatas, penulis dapat menyampaikan beberapa masukan dan saran sebagai berikut:

1. Kepada Kepala Sekolah Program bimbingan dan konseling yang sudah terjadwal sebaiknya dilaksanakan dengan berkesinambungan dengan memodifikasi kegiatan pelaksanaan program bimbingan dan konseling sebagai edu-entertainment.
Mengadakan seminar, sarasehan dengan topik atau thema misalnya: Bagaimana cara mengatasi kecemasan menjelang Ujian Akhir Nasional ditinjau dari aspek psikologis dengan pendekatan perspektif religius dengan mengundang nara sumber yang dianggap kompeten dibidangnya. Setiap sebulan sekali atau seminggu sekali mengadakan pengajian dan sholat dhuha bersama, doa bersama dan kegiatan keagamaan lainnya.

2. Kepada Guru Bimbingan dan Konseling disarankan lebih optimal dalam melaksanakan program birnbingan dan konseling di sekolah, agar siswa Iebih merasakan layanan dan bimbingan konseling yang ada di sekolah. Menindak lanjuti butir 9. butir 12. butir. 16.butir 19.dan butir 22, untuk lebih intens

\section{DAFTAR PUSTAKA}

Abu Ahmadi, (1991), Psikologi Umum, Jakarta : Rineka Cipta

Amti, Erman dan Prayitno. (2004). DasarDasar Bimbingan dan Konseling. Jakarta: PT. Rineka Cipta.

Arifm, H.M, (1982). Pedoman Pelakasanaa Bimbingan dan Penyeluhan Agama. Jakarta: PT.Golden Terayon Press.

Arikanto, Siharsimi, (1996). Prosedur Penelitian Suatu Pendekatan Praktek,Jakarta:PT Rineka Cipta.

Daradjat, Zakiah. (2001). Kesehatan Mental. Jakarta: Toko Gtmung Agung.

Depdikbud, (2003). Undang-Undang Republik Indonesia No. 20 tahun 2003, 2008, Sistem Pendidikan Nasional, Jakarta:Depdikbud

Djumhur I. dan Moh. Surya, (1998). Bimbingan dan Penyuluhan di Sekolah CV. Ilmu, Bandung

Djumhur dan Moh. Surya, (2009). Psikologi Konseling, Bandung,:Maestro

EI-Quusy, Abdul Aziz, (1986). Pokok-Pokok Kesehatan Jiwa. Jakarta: PT BulanBintang.

Hamdani : 2012, Bimbingan dan Penyuluhan . Bandung : Pustaka Setia

Hastuti dan Winkel,W.S, (2004). Bimbingan dan Konseling Di Institusi Pendidikan. Yogyakarta: Media Abadi. 
Kartika, M, (2011). Landasan Kependidikan dan Problematika Pendidikan, Dampak Positif dan negatif adanya ujian nasional

Natawijaya Rahman, (1998). Peranan Guru Dalam Bimhingan di Sekolah, Bandung:CV Abrair.

Poerwardarminta, W. J. S, (1984). Kamus Umum Bahasa Indonesia. Jakarta: Balai Pustaka

Prayitno dan Erman Amti, (2004). Dasar-Dasar Bimbingan dan Konseling. Jakarta: Rineka Tjipta

Sartono dan Umar, HM, (1998). Bimbingan dan Penyuluhan Untuk Fakultas Tarbiyah dan Komponen MKDK. Jakarta: CV Pustaka Setia.
Singgih Gunarsa, (2007). Dasar-Dasar Teori Perkembangan Anak, Jakarta,: PT BPK Gunung Muli

Syamsu Yusuf dan Juntika Nurihsan, (2006). Landasan Bimbingan dan Konseling, Bandung: Remaja Rosdakarya

http://vanny3august.blogspot.com/2012/03peng ertian ujian nasional.html

http://rohmatulummah19.blogspot.com/p/faktor -faktor yang mempengaaruhi ujian nasional.html

http://aprilliagustina.blogspot.com/2012/12 makalah keceamasan siswa dalam .html

http://wwwfacebook.com/notes/rizalalams/kond isi-psikologis-siswa dalam menghadapi ujiannasional-cara mengatasinya/370998619586856 